\title{
PRECIPITATION TRENDS IN THE KALU GANGA BASIN IN SRI LANKA
}

\author{
A.D.Ampitiyawatta ${ }^{1}$, Shenglian Guo ${ }^{2}$
}

\begin{abstract}
Kalu Ganga basin is one of the most important river basins in Sri Lanka which receives very high rainfalls and has higher discharges. Due to its hydrological and topographical characteristics, the lower flood plain suffers from frequent floods and it affects socioeconomic profile greatly. During the past several years, many researchers have investigated climatic changes of main river basins of the country, but no studies have been done on climatic changes in Kalu Ganga basin. Therefore, the objective of this study was to investigate precipitation trends in Kalu Ganga basin. Annual and monthly precipitation trends were detected with Mann-Kendall statistical test. Negative trends of annual precipitation were found in all the analyzed rainfall gauging stations. As an average, -0.98 trend with the annual rainfall reduction of $12.03 \mathrm{~mm} /$ year was found. April and August were observed to have strong decreasing trends. July and November displayed strong increasing trends. In conclusion, whole the Kalu Ganga basin has a decreasing trend of annual precipitation and it is clear that slight climatic changes may have affected the magnitude and timing of the precipitation within the study area
\end{abstract}

Key words: Kalu Ganga basin, precipitation, trend, Mann-Kendall statistical test.

\section{INTRODUCTION}

Kalu Ganga basin is the second largest river basin in Sri Lanka covering $2766 \mathrm{~km}^{2}$ and much of the catchment is located in the highest rainfall area of the country, which reflects the high annual rainfall. The annual rainfall in the basin is averaged to $4000 \mathrm{~mm}$ and leads to 4000 million $\mathrm{m}^{3}$ of annual flow.The Kalu Ganga originates from the central hills of wet zone at an altitude of $2250 \mathrm{~m}$ and garners rainfall on the western slopes and falls out to the sea at Kalutara after traversing about $129 \mathrm{~km}$. The basin has steep gradients in upper part and mild gradients in lower part. Due to these hydrological and topographical characteristics of the river basin, its lower flood plain suffers from frequent floods during the Southwest monsoon season. Therefore, the damages to the socioeconomic profile are significantly high since the lower flood plain of Kalu Ganga is densely populated and it is a potential area for rice production. During the past several years, attention has been paid to study on precipitation changes of main river basins of Sri Lanka. Lareef (2003a) studied El Niño-southern oscillation (ENSO) influences on rainfall and stream flow in the upper catchment of Mahaweli River. Lareef (2003b) also investigated the El Niño-southern oscillation influences on stream flow in Kelani River. Smakhtin and Weragala (2005) have studied hydrology and environmental flows in the Walawe River basin. However, we couldn't find any academic literature regarding climatic changes in Kalu Ganga basin, which is one of the four main rivers in Sri Lanka. The major possible effects of climate change may include variability in water resources, increase desertification, loss of biodiversity and changes in

\footnotetext{
${ }^{I}$ Faculty of Agricultural Sciences, Sabaragamuwa University of Sri Lanka, Sri Lanka

${ }^{2}$ State Key Laboratory of Water Resources and Hydropower Engineering Science, Wuhan University, Wuhan, Hubei Province, 430072, China
} 
agricultural productivity (Burlando and Rosso, 2002). One of the most significant consequences resulting from climate change may be the alteration of regional hydrological cycles and subsequent changes in stream flow regimes. Studies of general circulation model (GCM) reveals that increased global temperature could lead to increase the amount and intensity of regional precipitation. Precipitation is a good indication of the impacts from climate change on water resources. Changes in precipitation patterns are very important for water resources managers to deal with the water resources planning and management. Variations in precipitation over daily, seasonal, annual, and decadal timescales influencewater resource systems. In addition to the studies on short-term variability of precipitation, long-term detection of precipitation is essential for understanding the potential impacts on water resources resulting from climate change. Therefore, the objective of this study was to investigate long-term precipitation trends, which is one of the crucial parameters in climatic change, in Kalu Ganga basin.

\section{MATERIALS AND METHODS}

\section{Data}

There are several principles related to the studies on detection of trends in timeseries. The first one is the length of the data records. Long-term data records are essential for detecting trends (Westmacott and Burn, 1997). To gain the spatial variability, 8 rain gauging stations were selected, in order to cover the whole geographical area of Kalu Ganga basin for the purpose of analyze. Locations of gauging stations are shown in Figure 01. Monthly and annual precipitation data from 1965 to 2004 were obtained from the Meteorological Department of Sri Lanka for the above selected gauging stations. However, some missing data points were found for number of months and years in the data set. For gauges with 30 years or more of data, the entire period of records also needs no more than $10 \%$ missing data. All the selected gauging stations are satisfied with this principle and all stations generally have at least 30 years of records. This length of data set satisfies the minimum required length in searching for evidence of climate change in hydroclimatic time-series as proposed by Burn and Elnur (2002) and Kahya and Kalayci (2004).

\section{Characters of precipitation in Kalu Ganga basin}

Although the Kalu Ganga has the second largest catchment in the country, it discharges the largest amount of water to the sea and it is in the order of 4000 milllion $\mathrm{m}^{3}$. This is due to large scale water regulation projects in the Mahaweli River basin with large reservoirs (Dharmasena, 2006), which has the largest river basin. Another interesting characteristic of the Kalu Ganga basin is that it accounts for the largest amount of annual per capita water availability. It is about $7750 \mathrm{~m}^{3}$ which is far more than the annual per capita water availability at national level of $2300 \mathrm{~m}^{3}$ (Imbulana and Neupane, 2003).

According to the previous researches, the annual average precipitation in the Kalu Ganga basin is about $4000 \mathrm{~mm}$. Imbulana and Neupane (2003) has found it as 3809 $\mathrm{mm}$. In the current study it has been found as $3818 \mathrm{~mm}$. The figures are very much closer and it further verifies the average annual precipitation of the basin. Table 01 shows the average annual precipitation of gauging stations and Kalu Ganga basin during the study period. It reveals that the upper catchment receives higher rainfall than the lower catchment and precipitation gradually decreases from central hills where Kalu Ganga origins to where it discharges to the sea. 




Figure 01: Kalu Ganga basin and rain gauge locations

Table 01: Average annual precipitation of gauging stations in Kalu Ganga basin

\begin{tabular}{lc}
\hline Gauging station & $\begin{array}{c}\text { Average Annual } \\
\text { precipitation }(\mathrm{mm})\end{array}$ \\
\hline Alupola & 4073.9 \\
Weddagala & 4146.3 \\
Ratnapura & 3922.6 \\
Kuruwita & 3875.5 \\
Galatura & 4110.8 \\
Geekiyanakanda & 3979.1 \\
Halwathura & 3708.6 \\
Kalutara & 2727.0 \\
\hline Kalu Ganga basin & 3818.0 \\
\hline
\end{tabular}



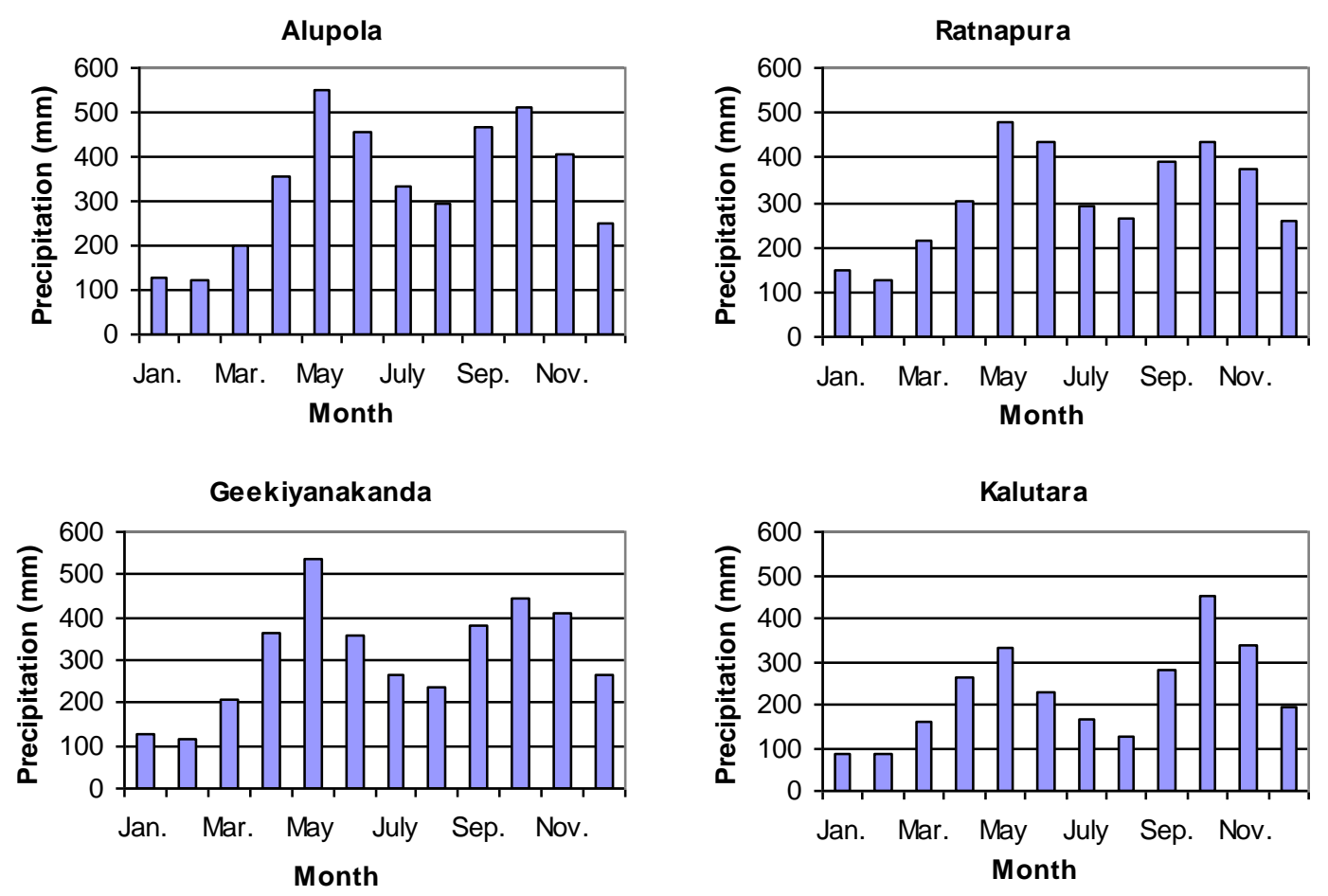

Figure 02: Monthly precipitation of four example gauging stations

Besides the slight variability of precipitation on a spatial scale, there also exists variability on the time scale. Figure 02 represents the several examples of monthly precipitation from upper catchment to lower catchment. It is clearly seen a bimodal rainfall pattern in the basin, where the two peaks are in the month of May and October. These heavy rainfalls are experienced at the beginning of southwest monsoon (May- September) and during the second inter monsoon(OctoberNovember). Additionally, considerable amount of rainfall receive during the first inter monsoon (March-April). Northeast monsoon gives comparatively less rainfall to the Kalu Ganga basin. Even though the February is the driest month, it receives more than $100 \mathrm{~mm}$ rainfall for most part of the basin.

\section{Long-term trend detection}

The plausible trends in precipitation are detected using the Mann-Kendall statistical test in this study. The MannKendall test, which was originally devised by Mann (1945) and further derived by Kendall (1975) as a non-parametric approach, has been widely used in different fields of research for the detection of trend in time series. These tests are widely used in environmental science because they are simple, robust and can cope with missing values and values below a detection limit. Therefore, it was found to be an effective tool for identifying trends in hydrology and water resources (e.g. Burn, 1994; Xu et al., 2003; Ludwig et al., 2004). The MannKendall test statistic is given as 


$$
Z_{m k}= \begin{cases}\frac{S-1}{\sqrt{\operatorname{var}(S)}} & S>0 \\ 0 & S=0 \\ \frac{S+1}{\sqrt{\operatorname{var}(S)}} & S<0\end{cases}
$$

in which,

$$
\begin{aligned}
& S=\sum_{i=1}^{n-1} \sum_{k=i+1}^{n} \operatorname{sgn}\left(x_{k}-x_{i}\right) \\
& \operatorname{var}(S)=\frac{n(n-1)(2 n+5)-\sum_{i} e_{i}\left(e_{i}-1\right)(2 e+5)}{18}
\end{aligned}
$$

In which the $Z_{m k}$, is the Mann-Kendall statistics, $x_{k}, x_{i}$ are the sequential data values, $n$ is the length of the data set, and $\operatorname{sgn}\left(x_{k}-x_{i}\right)$ is equal to $1,0,-1$ if $\theta$ is greater than, equal to, or less than zero respectively. $e_{i}$ is the extent of any given tie and $\sum$ denotes the summation over all ties.

The null hypothesis $H_{0}$ of no trend is accepted if $-Z_{1-\alpha / 2} \leq Z_{m k} \leq Z_{1-\alpha / 2}$.

Another useful index derived from the trend test is the magnitude of trend slope $\beta$, a non-parametric robust estimate. This indicates an increasing or decreasing tendency by a positive or negative value. The trend slope is defined as

$$
\beta=\operatorname{Median}\left(\frac{x_{i}-x_{j}}{i-j}\right) \quad \forall j<i
$$

A positive value of $\beta$ indicates an 'upward trend', i.e, increasing value with time, and a negative value of $\beta$ indicates a 'downward trend', i.e, decreasing values with time.

\section{RESULTS}

Based on the non-parametric MannKendall test, Mann-Kendall statistic $\left(Z_{m k}\right)$, which is the trend of precipitation and magnitude of trend slope $(\beta)$ are examined for monthly and annual cases. Mann-Kendall statistic $\left(Z_{m k}\right)$ is tested at $\alpha$ $=0.05$ significance level. At this significance level, Mann-Kendall statistic: the $\left|Z_{m k}\right|$ value $=Z_{1-\alpha / 2}=Z_{1-0.05 / 2}=1.96$.

\section{Long-term trend of annual precipitation}

Resulted Mann-Kendall statistic $\left(Z_{m k}\right)$ and magnitude of trend slope $(\beta)$ for annual precipitation at studied locations are shown in Table 02. 
Table 02: Mann-Kendall statistic and trend slope of the studied gauging stations

\begin{tabular}{lcc}
\hline Gauging station & $Z_{m k}$ & $\beta$ \\
\hline Alupola & -0.46 & -7.53 \\
Weddagala & -0.42 & -8.21 \\
Ratnapura & -0.45 & -6.63 \\
Kuruwita & -0.75 & -12.6 \\
Galatura & -0.50 & -8.36 \\
Geekiyanakanda & -2.76 & -28.32 \\
Halwathura & -0.89 & -10.06 \\
Kalutara & -1.63 & -15.29 \\
\hline
\end{tabular}

It is interesting to note that all the gauging locations show negative trend of annual precipitation. Kalutara, Halwathura and Geekiyanakanda, the places where gauging stations are located at downstream areas show some what higher negative trends and the long-term trend at Geekiyanakanda shows significant reduction of precipitation at $\alpha=0.05$ significance level. The trend slope, which is the reduction of precipitation, is $28.32 \mathrm{~mm} /$ year, a considerable reduction of annual precipitation. The annual trends of upstream locations are comparatively less and it is further decreasing when go to higher elevation areas such as Alupola and Weddagala. As an average basis, Kalu Ganga basin shows negative trend of precipitation with -0.98 and the reduction of precipitation is $12.03 \mathrm{~mm} /$ year.

\section{Long-term trend of monthly precipitation}

Table 03 presents the temporal distribution of monthly precipitation trends from January to December and Figure 03 represents the average trends with time. Accordingly, all the months show negative trends of precipitation with decreasing precipitation except January, July and November. However, no positive trends are found in the months of April and September from any gauging location. From February to June and August to October, most of the gauging stations show a decreasing trend; hence the average trend in the basin is a negative value indicating a reduction of precipitation with time.

It is interesting to note that some gauging stations show significant decreasing trend in the month of August. April and August months have highest negative trend. On the contrary, months with a larger positive trend are predominantly July and November. According to the spatial distribution of monthly rainfall, downstream gauging stations such as Kalutara, Geekiyanakanda and Halwathura show higher negative trends in most of the months. Alupola and Weddagala, where gauging stations are located in upstream region, show relatively less negative trend of monthly rainfall. 
Table 03: Magnitude of positive/negative and average trends for different months

\begin{tabular}{lccc}
\hline Month & $\begin{array}{c}\text { Positive } \\
\text { trend }\end{array}$ & $\begin{array}{c}\text { Negative } \\
\text { trend }\end{array}$ & $\begin{array}{c}\text { Average } \\
\text { trend }\end{array}$ \\
\hline January & 0.97 & -0.04 & 0.28 \\
February & 0.63 & -0.74 & -0.33 \\
March & 0.95 & -1.67 & -0.41 \\
April & - & -1.39 & -0.79 \\
May & 0.75 & -0.84 & -0.26 \\
June & 0.75 & -0.88 & -0.33 \\
July & 1.02 & -0.22 & 0.43 \\
August & 0.22 & -2.20 & -0.86 \\
September & - & -0.90 & -0.77 \\
October & 0.39 & -1.00 & -0.63 \\
November & 1.09 & -0.18 & 0.47 \\
December & 0.24 & -1.48 & -0.37 \\
\hline
\end{tabular}

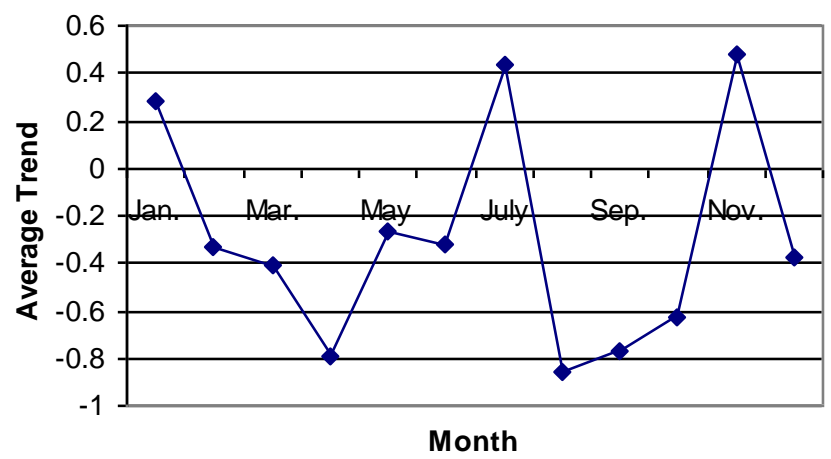

Figure 03: Temporal distribution of average trend over the year

\section{DISCUSSION}

Trends have been detected for precipitation in Kalu Ganga basin from 1965 to 2004. A systematic analysis for the 30-40 years of records provide a general picture of how the precipitation has changed in the past several decades. A decreasing trend for annual precipitation was found across all the gauging locations in Kalu Ganga basin. The decreasing trend is more severe in downstream areas rather than the upstream areas. A significant decreasing trend of annual precipitation was detected at Geekiyanakanda, a location which is in the downstream region.

In the analysis of long-term trend of monthly rainfall, most of the months showed decreasing trend. The upward trend in July and November and downward trend in May and October dictated that a shift of peak precipitation months by two months and one months backward with changing the regional hydrological cycle. Therefore, it would be expected decreasing rainfalls in May and increasing rainfalls in July. The same phenomena would happen in the months of October and November. According to the current study, it is clear that slight climatic changes may have affected the magnitude and timing of the precipitation within the study area. Therefore, it is essential to understand the consequences of climatechange influences on water resources, and the impacts of these changes will have on the planning and management strategies for present and future water resources. It should be noted that there are some limitations when detecting trends based on 
limited data. The main limitation is missing rainfall data of every gauging station. Another limitation is the length of data records. Some gauging stations have 40 years of records and some stations have 30 years of records.

\section{CONCLUSION}

Whole the Kalu Ganga basin has a decreasing trend of annual precipitation. As an average, it is a -0.98 trend with the annual rainfall reduction of 12.03 $\mathrm{mm} /$ year. From the monthly precipitation, April and August were observed to have strong decreasing trends. July and November displayed strong increasing trends. Hopefully, the information provided by trends detection may provide some useful references for water resources planning and management in the study area.

\section{ACKNOLEGEMENT}

The authors are grateful to the Meteorological Department of Sri Lanka for providing useful precipitation data.

\section{References}

Burlando, P. and R. Rosso (2002). Effects of transient climate change on basin hydrology. 1. Precipitation scenarios for the Arno River, central Italy. Hydrological Processes, 16(6): pp 1151-1175.

Burn, D.H. (1994). Hydrologic effects of climate change in west-central Canada. Journal of Hydrology, 160(1): pp. 53-70.

Burn, D.H. and M.A.H. Elnur (2002). Detection of hydrologic trends and variability. Journal of Hydrology, 255(1): pp. 107-122.

Dharmasena, G.T. (2006). Integrated water resources management and sound information system-Sri Lankan experience. $32^{\text {nd }}$ WEDC International conference, Colombo, Sri Lanka.

Imbulana, K.A.U.S. and B.R. Neupane (2003). Integrated water resources management: The relevance of indications for measuring river basin status and performance. Proceedings of MTM-IV-Indicators for measuring river basin status and performace. Netherlands, pp 91-101.

Kahya, E. and S. Kalayci (2004). Trend analysis of streamflow in Turkey. Journal of Hydrology, 289(2): pp 128-144.

Kendall, M.G. (1975). Rank Correlation methods. Charles Griffin, London.

Lareef, Z. (2003a). El Nino-southern oscillation influences on the Mahaweli streamflow in Sri Lanka. International Journal of Climatology, 23(1): pp 91-102.

Lareef, Z. (2003b). Sensitivity of Kelani streamflow in Sri Lnaka to ENSO. Hydrological Process, 17(12): pp 2439-2448.

Ludwig, W., Serrat, P., Cesmat, L, and J. Garcia-Esteves (2004). Evaluating the impact of the recent temperature increase on the hydrology of the Têt River (southern France). Journal of Hydrology, 289(1): pp. 204-221.

Mann, H.B. (1945). Non parametric test against trend. Econometrica, 13: pp 245-259.

Smakhtin, V. and N. Weragala (2005). An Assessment of Hydrology and Environmental Flows in the Walawe River Basin, Sri Lanka. Working Paper 103. International Water Management Institute (IWMI), Colombo, Sri Lanka. 
Westmacott, J.R. and D.H. Burn (1997). Climate change effects on the hydrologic regime within the Churchill-Nelson River Basin. Journal of Hydrology, 202(1), pp 263-279.

$\mathrm{Xu}, \mathrm{Z} . X$. , Takeuchi, K. and H. Ishidaira (2003). Monotonic trend and step changes in Japanese precipitation. Journal of Hydrology, 279(3), pp 144-150. 